ISSN 1392-3196 / e-ISSN 2335-8947

Zemdirbyste-Agriculture, vol. 103, No. 2 (2016), p. 221-228

DOI 10.13080/z-a.2016.103.029

\title{
Optimization of irrigation-drainage scheme for tomato crop based on multi-index analysis and projection pursuit model
}

\author{
Maomao HOU ${ }^{1}$, Xiaohou $\mathrm{SHAO}^{2,3}$ \\ ${ }^{1}$ College of Horticulture, Fujian Agriculture and Forestry University \\ Fuzhou, Fujian 350002, China \\ E-mail: njhoumaomao@126.com
}

${ }^{2}$ Key Laboratory of Efficient Irrigation-Drainage and Agricultural Soil-Water Environment in Southern China, Hohai University, Ministry of Education

Nanjing 210098, China

${ }^{3}$ College of Water Conservancy and Hydropower Engineering, Hohai University

Nanjing 210098, China

\begin{abstract}
Various indexes should be considered when developing a suitable irrigation and drainage scheme for crops. Our study chosen tomato as plant material and conducted a field experiment under saline soils. Nine treatments distinguished by different irrigation quotas and different drain ditch depths were used for the optimization of irrigation-drainage scheme. A flooding irrigation treatment with no surface drainage was adopted as control. The system of evaluation indexes was established in comprehensive consideration of the electrical conductivity and nutrient of soil, and the water use efficiency, nitrogen use efficiency, quality and marketable yield of tomato. Moreover, the multi-index analysis and projection pursuit (PP) model were used to evaluate the irrigation-drainage schemes according to the observed values of these six evaluation indexes. Results showed that different irrigationdrainage treatments decreased the electrical conductivity in plough layer by $24.6-51.3 \%$, and increased the tomato water use efficiency and nitrogen use efficiency by $0.3-24.2 \%$ and $20.3-96.0 \%$, respectively. The tomato marketable yield was increased by $14.4-31.3 \%$ with the irrigation-drainage treatments when compared to the control. As analyzed by the PP model, I3D1 $\left(300 \mathrm{~m}^{3} \mathrm{hm}^{-2}\right.$ of irrigation quota combined with $10 \mathrm{~cm}$ of ditch depth) was the treatment that possessed best comprehensive benefits due to the highest projection value of 1.6724 thus was recommended by this study as the optimal irrigation-drainage scheme.
\end{abstract}

Key words: drip irrigation, irrigation quota, principal component analysis, projection pursuit, surface drainage.

\section{Introduction}

Mulched drip irrigation and surface drainage are two ways to control salinity of cultivated soils in coastal area. However, except for the effects on soil salts, mulched drip irrigation and surface drainage also have various effects on other indicators of plant-soil system, such as the crop yield (Raina et al., 2013), quality (Mahajan, Singh, 2006), soil nutrients (Vázquez et al., 2006; Parris, 2011), water use of crops (Wan et al., 2007) and so on. Therefore, when selecting optimal parameters of irrigation-drainage scheme such as the irrigation quota and the drain ditch depth for saline areas, the saltremoving result cannot be the only considered factor as mulched drip irrigation and surface drainage will affect the aforementioned indicators. Other factors, including the water use efficiency (WUE), nitrogen use efficiency (NUE), crop quality indicators and crop yield should also get enough attention.

Usually, the optimization of irrigation and drainage scheme in consideration with various indexes needs the help of multi-index evaluation models (Shao, Zhang, 2007). The projection pursuit (PP) model, as a classic multi-index evaluation model, has been widely used in the optimization of agricultural water schemes (Ma, 2009; Hou et al., 2012; Shao et al., 2012). The PP model is proved to be an efficacious approach in dealing with high-dimensional data, especially those distributed nonlinearitily and irregularly. In practical operation, the PP model uses the computer technology to project the high-dimensional data to low-dimensional space, and search for the projection value which can well reflect the characters of high-dimensional data, in order to reduce the dimension of data (Croux et al., 2007). However, some of the evaluation indexes contain many subitems (for example, the tomato quality index usually contains sugar, sugar:acid ratio, vitamin $\mathrm{C}$, soluble solid and so on). If all these subitems are put into the index system paralleled with other evaluation indexes which contains no subitems, the distribution of index weight will be 
uneven. Therefore, how to turn the various subitems into one comprehensive evaluation index deserved to be considered.

In this study, the tomato, which was sensitive to soil moisture variation, was chosen as the plant material. Tomatoes were planted in the coastal saline soils under mulch drip irrigation in eastern China. Surface drainage was conducted during the growth duration of tomato. The experimental treatments contained three irrigation quotas and three drain ditch depths. The irrigation-drainage schemes were evaluated in comprehensive consideration of their effects on the salt-decreasing rate, soil available nutrient content, tomato WUE, NUE, quality and marketable yield. In order to solve the problem of uneven distribution of index weight, we used principal component analysis (PCA) to pretreat the tomato quality indicators and the soil nutrient indicators, and then used the PP model to optimize the irrigation and drainage scheme. This new attempt was expected to provide useful information for improving the comprehensive benefit of agricultural production in similar area.

\section{Material and methods}

Experimental site. The experiments were carried out from June to September in 2015 at Hangzhou Bay, Ningbo (latitude $30^{\circ} 10^{\prime} \mathrm{N}$, longitude $121^{\circ} 13^{\prime} \mathrm{E}$ ), China (the experiments were permitted by the owner of the land He Han). The experimental site enjoys a subtropical, mild climate with four distinctive seasons. The mean annual temperature of Ningbo from 1961 to 2010 is $16.4^{\circ} \mathrm{C}$. The temperature of July is the highest, with a mean annual value of $28^{\circ} \mathrm{C}$, and that of January is the lowest, with a mean annual value of $4.7^{\circ} \mathrm{C}$. The frost-fee period is 230-240 days. The mean annual sunshine hours of the experimental field are $1850 \mathrm{~h}$. Besides, the experimental site has a mean annual precipitation of $1480 \mathrm{~mm}$, and most of it occurs during the period between May and September, the precipitation during this period accounted for more than $60 \%$ of the total. The experimental field is located at the Development Zone of Hangzhou Bay. The soil in the field was mixed uniformly before the experiment. The soil type of the experimental fields is medium-textured soil, with bulk density of $1.46 \mathrm{~g} \mathrm{~cm}^{-3}$, $0-60 \mathrm{~cm}$ organic matter of $0.928 \%, 0-60 \mathrm{~cm}$ total salt of $3.47 \mathrm{~g} \mathrm{~kg}^{-1}$, available nitrogen $(\mathrm{N})$ of $44.33 \mathrm{mg} \mathrm{kg}^{-1}$, available phosphorus (P) of $52.10 \mathrm{mg} \mathrm{kg}^{-1}$ and available potassium (K) of $151.81 \mathrm{mg} \mathrm{kg}^{-1}$.

Plant material and arrangement. Tomato variety 'Red Crown' was adopted as the plant material. The young tomato seedlings with six expanded leaves were transplanted into the fields on 10 June. The seedlings were arranged with $30 \mathrm{~cm}$ plant spacing and $40 \mathrm{~cm}$ row spacing. Two lines of tomatoes were irrigated by one drip pipe between them, and were mulched with one single white plastic film. The plant arrangement was displayed in Figure 1.

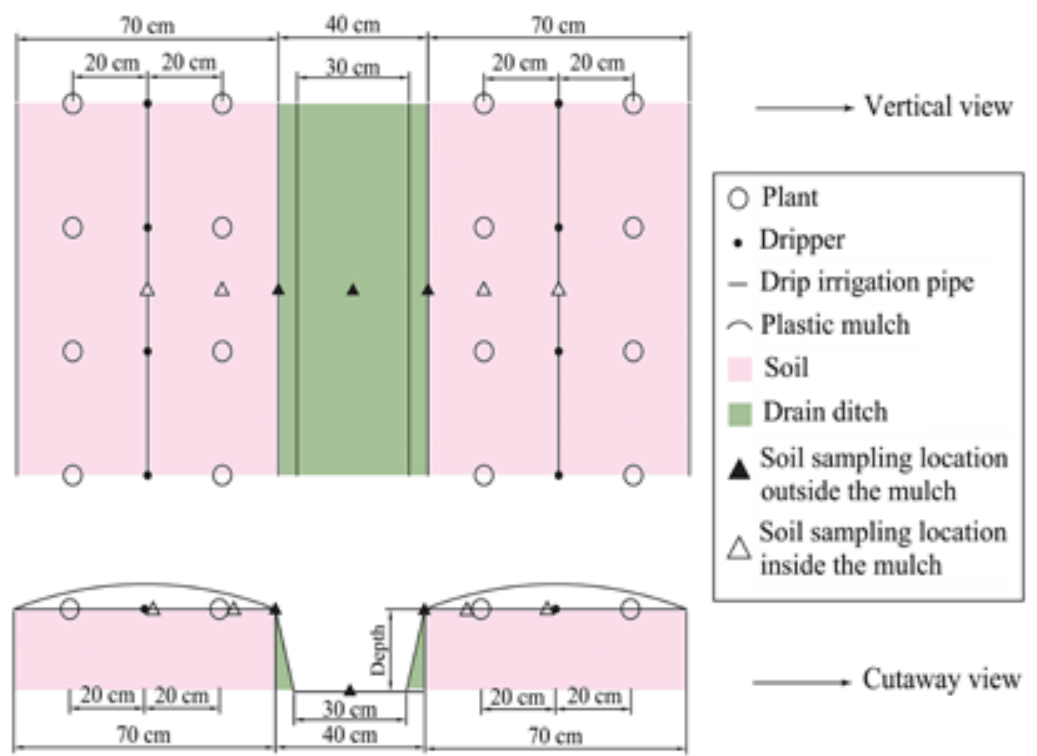

Figure 1. The plant arrangement and the locations of soil samples

Before transplanting, the tomatoes were fertilized with $650 \mathrm{~kg} \mathrm{hm}^{-2}$ compound fertilizer $\left(\mathrm{N}_{2} \mathrm{P}_{2} \mathrm{O}_{5}: \mathrm{K}_{2} \mathrm{O}=\right.$ $1: 2: 2)$. Other field management procedures were applied equally to all the tomatoes. No additional light, heat or $\mathrm{CO}_{2}$ were provided.

During the growth stage of tomato, the lateral branches were removed, each tomato plant was allowed to reserve four fruit sequences. Pest control was conducted based on the actual situation in the experimental fields.

Treatments and experimental design. Ten treatments were used to evaluate the combined effects of mulched drip irrigation and surface drainage on the saline soils, tomato quality and yield. Each treatment occupied an area of $1.8 \times 6 \mathrm{~m}^{2}$, and total area of the experimental field was $520 \mathrm{~m}^{2}$. Different treatments were arranged in one line. The planting density of tomato was 60 plants per treatment. These treatments were distinguished by different quotas of drip irrigation and different depths of drain ditches. The irrigation quotas were kept as three levels of $200 \mathrm{~m}^{3} \mathrm{hm}^{-2}$ (I1), $250 \mathrm{~m}^{3} \mathrm{hm}^{-2}$ (I2) and $300 \mathrm{~m}^{3} \mathrm{hm}^{-2}$ (I3). The drain ditches were excavated as three different depths of 10 (D1), 20 (D2) and 30 (D3) $\mathrm{cm}$, but as the same top width of $40 \mathrm{~cm}$ and bottom width of $30 \mathrm{~cm}$ (Fig. 1). A pouring irrigation treatment with $250 \mathrm{~m}^{3} \mathrm{hm}^{-2}$ quota but has no surface drainage was adopted as control. Each treatment was replicated three times. The treatments are shown in Table 1. 
Table 1. Experimental design

\begin{tabular}{ccccccccccc}
\hline Treatment & I1D1 & I2D1 & I3D1 & I1D2 & I2D2 & I3D2 & I1D3 & I2D3 & I3D3 & Control \\
\hline Irrigation quota $\mathrm{m}^{3} \mathrm{hm}^{-2}$ & 200 & 250 & 300 & 200 & 250 & 300 & 200 & 250 & 300 & 250 \\
Depth of drain ditch cm & 10 & 10 & 10 & 20 & 20 & 20 & 30 & 30 & 30 & 0 \\
\hline
\end{tabular}

The tomatoes were irrigated every seven days since 12 June (Table 2). During the whole growth stage, the tomatoes were irrigated thirteen times in total. The surface drainages were conducted three times on 15 July, 12 August and 20 September, respectively (Table 2 ). For each time, the drainage flow was $3.2 \mathrm{~L} \mathrm{~s}^{-1}$ the drainage duration was 30 min. On 15 July and 12 August, the surface drainage was directly conducted, while which on 20 September was carried out after uncovering the mulch.

Rainproof facilities were installed above the experimental fields to prevent the precipitation from influencing the soil moisture during the experiment. The rainproof facilities were half-finished multi-span greenhouse but without the pad and fan cooling system. The greenhouse had a cambered top, with span of $8 \mathrm{~m}$, shoulder height of $3 \mathrm{~m}$, frontal width of $4 \mathrm{~m}$ and space between two arches of $1 \mathrm{~m}$. The greenhouse was covered with white films, and the films were laid down manually during the rainy periods.

Samples and measurements. Each treatment had seven representative sampling points. These points were in one line perpendicular to the drip pipe. The sampling points were located separately at the midpoint between the two drippers, the midpoint between the two tomato plants, the outer edge of the mulch and the middle of the drain ditch. Furthermore, the sampling points were divided into two different categories based on their locations: the sampling locations outside the mulch (SOM) and the sampling locations inside the mulch (SIM), as marked in Figure 1. Before and after the irrigation, the soil electrical conductivity (EC) value was measured by an analyzer HH2/WET (DELTA-T Company, England). Similarly, before and after the last drainage, the soil EC was also measured. EC value in SIM was the average of the four sampling points inside the mulch, and which in SOM was the mean of the three sampling points outside the mulch. The soil samples at $0-20 \mathrm{~cm}$ depth were collected then treated for measuring the available $\mathrm{N}$, available $\mathrm{P}$ and available $\mathrm{K}$ content. The date of soil sampling was 21 September.

Among the four lines of tomato in one treatment, the two lines nearer to the drain ditch were used to observe the tomato quality and yield. At maturity, twelve fruit samples from six plants in each treatment were randomly collected. For each fruit, $10 \mathrm{~g}$ of tomato flesh was taken along the longitudinal axis and then homogenized for quality measurements. The following components contributed greatly to the tomato quality: volume, density, soluble solids, total acid, vitamin $\mathrm{C}$ and sugar:acid ratio (Zhai et al., 2015). At each harvest time, the number and weight of tomato was recorded, and the tomato yield was calculated at the end of the last harvest. The tomato marketable yield was the total yield minus the yield of deformed and diseased tomatoes.

Tomato water use efficiency (WUE) $\left(\mathrm{kg} \mathrm{m}^{-3}\right)$ was calculated by the following equation (Chen et al., 2013): $W U E=Y / E Y$, where $Y$ was the tomato yield $\left(\mathrm{t} \mathrm{ha}^{-1}\right), E T$ - the evapotranspiration (mm).

Evapotranspiration (ET) was calculated using the water balance equation of the farm land (Xing, Zhang, 2015): $E T=P+I+U-R-D-\Delta W$, where $P$ was the valid rainfall $(\mathrm{mm}), I-$ the irrigation amount $(\mathrm{mm}), U-$ the groundwater recharge $(\mathrm{mm}), R-$ the runoff $(\mathrm{mm})$, $D$ - the deep percolation ( $\mathrm{mm})$, and $\Delta W$ - the variation of soil moisture before and after the experiment (mm). For this study, $P, U, R$ and $D$ could be ignored. The equation could thus be simplified as: $E T=I-\Delta W$.

Tomato nitrogen use efficiency (NUE) $(\%)$ was calculated using the following equation (Zotarelli et al., 2009): $N U E=N_{p} /\left(N_{F}+N_{S}\right) \times 100 \%$, where $N_{p}$ is the nitrogen amount that absorbed by tomato plant $\left(\mathrm{kg} \mathrm{ha}^{-1}\right), N_{F}$ - the nitrogen amount that applied $\left(\mathrm{kg} \mathrm{ha}^{-1}\right), N_{S}$ - the original nitrogen amount in soil at $0-20 \mathrm{~cm}$ depth $\left(\mathrm{kg} \mathrm{ha}^{-1}\right)$.

Structure of evaluation indexes. The structure of evaluation indexes is shown in Figure 2 (Yan, 2014).

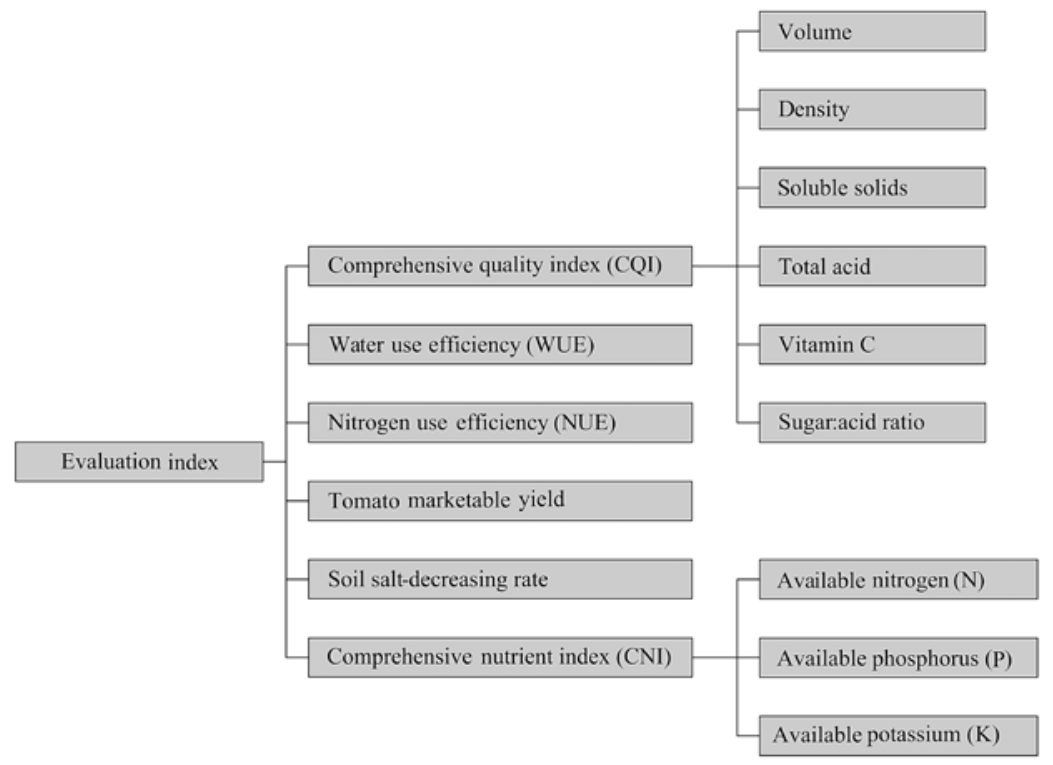

Figure 2. Evaluation indexes of the irrigation and drainage scheme 
Principal component analysis (PCA) model. The PCA model was used to summarize the various quality indexes into one comprehensive quality index (CQI) to facilitate the evaluations on the overall quality of tomato. The principal components of the quality indexes were extracted by PCA, and the value of the main component and the percentage contribution of that component to the total variation were obtained after the extraction. The value of CQI was calculated using a membership function based on the value of the main component and percentage contribution. Detailed calculations are specified in (Shao et al., 2014). Similarly, soil available N, P and K were summarized by PCA model into a comprehensive nutrient index $(\mathrm{CNI})$ to evaluate the overall fertility of soil.

Projection pursuit (PP) model. The calculations of PP model are as the following steps (Shao, Zhang, 2007):

(1) Establish the evaluation matrix; if the scheme number is $n$, the index number is $p$, the $j^{\text {th }}$ index in the $i^{\text {th }}$ scheme is $x_{i j}^{*}$, then the evaluation indexes could be expressed by an $n \times p$ matrix; in our study $p=10, n=6$.

(2) Normalize the evaluation indexes; the following measures are taken in order to eliminate the dimension discrepancy among different indexes:

for the indexes that are expected to possess higher index value (all six indexes in our study are expected to have higher index value):

$$
x_{i j}=\frac{x_{i j}-\min \left(x_{j}^{*}\right)}{\max \left(x_{j}^{*}\right)-\min \left(x_{j}^{*}\right)} ;
$$

for the indexes that are expected to possess lower index value:

$$
x_{i j}=\frac{\max \left(x_{j}^{*}\right)-x_{i j}}{\max \left(x_{j}^{*}\right)-\min \left(x_{j}^{*}\right)} .
$$

Thus a new $n \times p$ matrix $X$ can be obtained based on the normalized indexes.

(3) Linear projection; the essence of linear projection is to observe the data from different angles and to search for the best projective direction which can well reflect the characters of the data. To do so, the unit vector $a=\left\{a_{1}, a_{2}, \ldots a_{p}\right\}$ was supposed as the one dimensional projective direction, and $z_{i}$ was supposed as the one dimensional projective eigenvalue:

$$
z_{i}=\sum_{j=1}^{p} a_{j} \times x_{i j}(i=1,2,3 \ldots, n ; j=1,2,3 \ldots p) .
$$

(4) Construct an object function for projection; the object function was expressed as the product of the distances between classes and the density between classes:

$$
Q_{\text {(a) }}=S_{Z} \times D_{Z}
$$

where $S z$ is the standard value of projective eigenvalue $\left(z_{i}\right)$, and is also named as distances between classes; $D z$ is the density between classes of $z_{i}$.

$$
S_{Z}=\sqrt{\frac{\sum_{i=1}^{n}\left(z_{i}-E(z)\right)^{2}}{n-1}},
$$

where $E(z)$ is the average of the array $\left\{z_{i} \mid i=1\right.$ $\sim n \mid\}$.

$$
D_{Z}=\sum_{i=1}^{n} \sum_{k=1}^{n}\left(R-r_{i k}\right) \times f\left(R-r_{i k}\right),
$$

where $R$ is window radius of local density;

$$
\begin{aligned}
& r_{i k}=\left|r_{i}-r_{k}\right| \\
& f(t)= \begin{cases}0 & t \geq 0 \\
1 & t \leq 0\end{cases} \\
& i, k=1,2,3 \ldots \\
&
\end{aligned}
$$

(5) Optimize the object function:

$$
\begin{aligned}
& \max Q_{(\mathrm{a})}=S_{Z} \times D_{Z} \\
& \text { s.t. } \sum_{j=1}^{p} a^{2}(j)=1, \\
& |a(j)| \leq 1 .
\end{aligned}
$$

(6) Evaluation; the contribution of evaluation index (index weight) can be obtained according to the best projective direction. According to the rules of the PP model, the better scheme possessed a higher $z_{i}$ value.

The projection pursuit classification model (PP) was built by software Matlab 7.1, and the real coding based accelerating genetic algorithm $(R A G A)$ was used to optimize the PP model. During the optimization process, the main parameters were set as: the original population size $S=400$, the crossover probability $P c=0.8$, the mutation probability $\mathrm{Pm}=0.8$, the excellent individual number $N=20$ and the accelerating times $T=20$.

Statistical analysis. Data were compared statistically by Duncan's multiple range test at the 0.05 probability level in software SPSS, version 17.0. Data for the PCA model were also submitted to the software SPSS to calculate the value of CQI and CNI.

\section{Results}

Soil electrical conductivity (EC). The soil EC in plough layer as measured for the treatments was shown in Table 2. After irrigation, the soil EC in SIM presented an obvious decline trend, whereas that in SOM increased. The treatments with higher irrigation quota resulted in obviously lower EC in SIM and higher EC in SOM correspondingly. Otherwise, the drain ditch depth also had some effects on soil EC in SOM, since the EC in SOM was higher under the lower ditch depth, and it should also be noted that the influence of ditch depth on EC was produced by the drainage on 15 July. After the irrigation, the lowest EC values in SIM and SOM were obtained by I3D1 and I2D3, and were 1.28 and $2.86 \mathrm{dS}$ $\mathrm{m}^{-1}$, respectively, as measured on 8 August.

After the drainage on 20 September, soil EC in SIM was decreased by the treatments (except for I1D2). But EC in SOM had not shown clear variation tendency. On 21 September, the lowest EC in SIM was still achieved by $\mathrm{I} 3 \mathrm{D} 1$, recording as $1.48 \mathrm{dS} \mathrm{m}^{-1}$, and the lowest EC of $2.14 \mathrm{dS} \mathrm{m}^{-1}$ in SOM was found in I1D1 treatment. The decreasing rate of EC during 10 June-21 September with the treatments was $40.6-62.0 \%$ and $8.5-$ $45.0 \%$, for SIM and SOM, respectively, and the average was $24.6-51.3 \%$. In comprehensive consideration of the salt-decreasing effect for both SIM and SOM, I3D1 was superior compared to the other treatments. Besides, at the end of the experiment, EC values (both in SIM and SOM) with different treatments were significantly $(p \leq 0.05)$ lower than those with control as measured on 21 September.

Soil available nutrient content. Soil available 
Table 2. Electrical conductivity (EC) of soil in plough layer

\begin{tabular}{ccccccccc}
\hline & \multicolumn{7}{c}{ Soil EC value in plough layer $\left(\mathrm{dS} \mathrm{m}{ }^{-1}\right)$} \\
\cline { 2 - 8 } Treatment & \multicolumn{2}{c}{7 August } & \multicolumn{2}{c}{8 August } & \multicolumn{2}{c}{20 September } & \multicolumn{2}{c}{21 September } \\
\cline { 2 - 9 } & SIM & SOM & SIM & SOM & SIM & SOM & SIM & SOM \\
\hline & $2.40 \mathrm{~b}$ & $3.20 \mathrm{~b}$ & $2.21 \mathrm{~b}$ & $3.36 \mathrm{c}$ & $2.24 \mathrm{bc}$ & $3.12 \mathrm{bc}$ & $2.10 \mathrm{bc}$ & $2.14 \mathrm{~d}$ \\
I1D1 & $2.08 \mathrm{c}$ & $2.40 \mathrm{~d}$ & $1.84 \mathrm{c}$ & $3.42 \mathrm{bc}$ & $2.16 \mathrm{bc}$ & $2.87 \mathrm{~cd}$ & $1.56 \mathrm{~d}$ & $2.27 \mathrm{~cd}$ \\
I2D1 & $1.92 \mathrm{~d}$ & $2.08 \mathrm{e}$ & $1.28 \mathrm{e}$ & $3.66 \mathrm{ab}$ & $1.98 \mathrm{c}$ & $2.23 \mathrm{~d}$ & $1.48 \mathrm{~d}$ & $2.31 \mathrm{~cd}$ \\
I3D1 & $2.51 \mathrm{~b}$ & $3.18 \mathrm{~b}$ & $2.24 \mathrm{~b}$ & $3.22 \mathrm{c}$ & $2.02 \mathrm{c}$ & $3.22 \mathrm{bc}$ & $2.12 \mathrm{bc}$ & $2.57 \mathrm{c}$ \\
I1D2 & $2.32 \mathrm{bc}$ & $3.20 \mathrm{~b}$ & $1.44 \mathrm{cde}$ & $3.36 \mathrm{c}$ & $2.45 \mathrm{~b}$ & $3.04 \mathrm{c}$ & $1.73 \mathrm{c}$ & $2.75 \mathrm{c}$ \\
I2D2 & $2.13 \mathrm{c}$ & $2.40 \mathrm{~d}$ & $1.76 \mathrm{c}$ & $3.52 \mathrm{bc}$ & $2.06 \mathrm{c}$ & $2.30 \mathrm{~d}$ & $1.88 \mathrm{c}$ & $2.58 \mathrm{c}$ \\
I3D2 & $2.40 \mathrm{~b}$ & $2.80 \mathrm{c}$ & $1.84 \mathrm{c}$ & $3.04 \mathrm{~cd}$ & $2.49 \mathrm{~b}$ & $3.34 \mathrm{~b}$ & $2.31 \mathrm{~b}$ & $3.56 \mathrm{~b}$ \\
I1D3 & $2.01 \mathrm{c}$ & $2.40 \mathrm{~d}$ & $1.60 \mathrm{~cd}$ & $2.86 \mathrm{~d}$ & $2.12 \mathrm{bc}$ & $2.87 \mathrm{~cd}$ & $2.10 \mathrm{bc}$ & $2.65 \mathrm{c}$ \\
I2D3 & $1.84 \mathrm{~d}$ & $2.56 \mathrm{~cd}$ & $1.36 \mathrm{de}$ & $3.17 \mathrm{c}$ & $2.09 \mathrm{bc}$ & $2.46 \mathrm{~d}$ & $1.88 \mathrm{c}$ & $2.37 \mathrm{~cd}$ \\
I3D3 & $2.88 \mathrm{a}$ & $3.82 \mathrm{a}$ & $2.56 \mathrm{a}$ & $3.82 \mathrm{a}$ & $2.99 \mathrm{a}$ & $3.94 \mathrm{a}$ & $2.99 \mathrm{a}$ & $3.94 \mathrm{a}$ \\
Control & & & & & & & &
\end{tabular}

Notes. The values of EC are means of three replications. In the same column, means followed by the same letter (a, b, c) do not differ significantly at the 5\% level according to Duncan's multiple range test. Sampling locations inside (SIM) and outside (SOM) the mulch represent the sampling location inside and outside the mulch, respectively.

nutrient content with different treatments is shown in Table 3 . The available $\mathrm{N}$ content of the treatments ranged from 43.6-53.2 $\mathrm{g} \mathrm{kg}^{-1}$, which was higher compared to control (except for I1D1 treatment), probably due to the fact that the soil moisture provided by I1D1 was not conductive enough to the mineralization of fertilizer elements. The available $\mathrm{N}$ content was positively related to the irrigation quota but has no obvious relationship with the ditch depth. Otherwise, the available P content was in a range of $37.3-44.8 \mathrm{mg} \mathrm{kg}^{-1}$. Most treatments decreased the available $\mathrm{P}$ content as compared to control, indicating that $\mathrm{P}$ was sensitive to the soil moisture and was easier to be washed away by irrigation water. The highest content of available P was in I1D3 treatment, followed by I1D2, no significant difference of available $\mathrm{P}$ content was found between them, this result suggested that the treatments applied with I1 irrigation quota was more effective in reserving available $\mathrm{P}$ in soil. The available $\mathrm{K}$ content was in a range of 149.3-163.8 $\mathrm{mg} \mathrm{kg}^{-1}$. The highest available $\mathrm{K}$ content was found in I3D2 treatment. However, the available $\mathrm{K}$ content with the irrigation-drainage treatments had no significant difference compared to control. Besides, it was found that both the irrigation quota and the ditch depth had no obvious effects on available $\mathrm{K}$ content.

Water use efficiency (WUE), nitrogen use efficiency (NUE) and tomato marketable yield. The WUE of the tomato with different treatments is shown in Table 4. The WUE with the treatments were in a range of $32.5-40.2 \mathrm{~kg} \mathrm{~m}^{-3}$. Generally, the WUE increased as the irrigation quota decreased. However, the WUE was not obviously affected by the ditch depth. The highest WUE of $40.2 \mathrm{~kg} \mathrm{~m}^{-3}$ was found with I1D2 treatment, which was significantly $(p \leq 0.05)$ higher compared to that with control. High values of WUE were also achieved by I1D1 and I1D3, and were 39.9 and $39.3 \mathrm{~kg} \mathrm{~m}^{-3}$, respectively.

Compared with control, the treatments increased the tomato NUE by a rate of $20.3-96.0 \%$ (Table 5). The highest NUE value of $60.4 \%$ was in I3D3 and the lowest one of $20.3 \%$ was found in I1D1. The NUE increased obviously as the irrigation quota increased, and the relationship between NUE and irrigation quota was especially significant in those treatments with D1 and D3 depth. Besides, the ditch depth also had some effects on NUE, although the effects were not that obvious compared to the irrigation quota. The NUE under deeper ditch depth appeared to be slightly higher.

The marketable yield of tomato with the treatments was increased by $14.4-31.3 \%$ compared to control (Table 4). The proportions of tomato marketable yield that accounted for the total yield were in a range of $89.1-97.5 \%$. The highest tomato marketable yield of $117.6 \mathrm{t} \mathrm{ha}^{-1}$ was found in I3D3, but which had no significant difference with that in I3D1 and I3D2. The marketable yield of tomato increased obviously as the irrigation quota increased, indicating that the irrigation quota played an important role in influencing the tomato yield formation. However, no obvious relationship was detected between the tomato marketable yield and the ditch depth.

Optimization of the irrigation and drainage

Table 3. Soil available nutrient $\left(\mathrm{mg} \mathrm{kg}^{-1}\right)$ in plough layer with different treatments

\begin{tabular}{cccc}
\hline Treatment & Available nitrogen $(\mathrm{N})$ & Available phosphorus $(\mathrm{P})$ & Available potassium $(\mathrm{K})$ \\
\hline I1D1 & $43.6 \mathrm{c}$ & $39.9 \mathrm{abc}$ & $149.3 \mathrm{~b}$ \\
I2D1 & $49.3 \mathrm{ab}$ & $41.3 \mathrm{abc}$ & $161.6 \mathrm{a}$ \\
I3D1 & $49.9 \mathrm{ab}$ & $38.5 \mathrm{bc}$ & $158.9 \mathrm{ab}$ \\
I1D2 & $45.6 \mathrm{bc}$ & $42.0 \mathrm{ab}$ & $158.8 \mathrm{ab}$ \\
I2D2 & $46.4 \mathrm{bc}$ & $40.5 \mathrm{abc}$ & $153.5 \mathrm{ab}$ \\
I3D2 & $53.2 \mathrm{a}$ & $37.3 \mathrm{c}$ & $163.8 \mathrm{a}$ \\
I1D3 & $46.4 \mathrm{bc}$ & $44.8 \mathrm{a}$ & $160.7 \mathrm{ab}$ \\
I2D3 & $50.3 \mathrm{ab}$ & $41.8 \mathrm{abc}$ & $150.7 \mathrm{ab}$ \\
I3D3 & $49.1 \mathrm{ab}$ & $40.0 \mathrm{abc}$ & $157.6 \mathrm{ab}$ \\
Control & $45.4 \mathrm{bc}$ & $42.7 \mathrm{ab}$ & $156.7 \mathrm{ab}$ \\
\hline
\end{tabular}

Note. Means in the same column followed by the same letter $(a, b, c)$ do not differ significantly at the $5 \%$ level according to Duncan's multiple range test. 
Table 4. Water use efficiency (WUE), nitrogen use efficiency (NUE) and tomato marketable yield

\begin{tabular}{|c|c|c|c|c|}
\hline \multirow[b]{2}{*}{ Treatment } & \multirow{2}{*}{$\begin{array}{l}\text { WUE } \\
\mathrm{kg} \mathrm{m}^{-3}\end{array}$} & \multirow{2}{*}{$\begin{array}{c}\text { NUE } \\
\%\end{array}$} & \multicolumn{2}{|c|}{ Tomato marketable } \\
\hline & & & $\begin{array}{l}\text { yield } \\
\mathrm{t} \mathrm{ha}^{-1}\end{array}$ & $\begin{array}{c}\text { proportion } \\
\%\end{array}$ \\
\hline I1D1 & $39.9 \mathrm{a}$ & $37.0 \mathrm{~d}$ & $104.2 \mathrm{ab}$ & 90.6 \\
\hline $\mathrm{I} 2 \mathrm{D} 1$ & $38.5 \mathrm{a}$ & $47.6 \mathrm{c}$ & $110.9 \mathrm{a}$ & 92.6 \\
\hline I3D1 & $36.5 \mathrm{ab}$ & $54.8 \mathrm{ab}$ & $115.3 \mathrm{a}$ & 89.8 \\
\hline I1D2 & $40.2 \mathrm{a}$ & $44.3 \mathrm{c}$ & $104.7 \mathrm{~b}$ & 93.7 \\
\hline $\mathrm{I} 2 \mathrm{D} 2$ & $36.7 \mathrm{ab}$ & $49.3 \mathrm{bc}$ & $111.2 \mathrm{ab}$ & 97.3 \\
\hline I3D2 & $33.3 \mathrm{c}$ & $51.5 \mathrm{bc}$ & $116.2 \mathrm{a}$ & 97.5 \\
\hline I1D3 & $39.3 \mathrm{a}$ & $47.8 \mathrm{bc}$ & $102.5 \mathrm{~b}$ & 94.5 \\
\hline I2D3 & $32.7 \mathrm{bc}$ & $51.1 \mathrm{bc}$ & $103.4 \mathrm{~b}$ & 94.5 \\
\hline I3D3 & $32.4 \mathrm{bc}$ & $60.4 \mathrm{a}$ & $117.6 \mathrm{a}$ & 95.1 \\
\hline Control & $32.3 \mathrm{c}$ & $30.8 \mathrm{~d}$ & $89.6 \mathrm{c}$ & 89.1 \\
\hline
\end{tabular}

Note. Means in the same column followed by the same letter $(\mathrm{a}, \mathrm{b}, \mathrm{c})$ do not differ significantly at the $5 \%$ level according to Duncan's multiple range test.

scheme. The quality indexes and their values used for calculating the comprehensive quality index of tomato were shown in Table 5. The EC-decreasing rate (Table 6), comprehensive nutrient index (CNI) (Table 6), water use efficiency (WUE) (Table 4), nitrogen use efficiency (NUE) (Table 4), comprehensive quality index (CQI) (Table 6) and tomato marketable yield (Table 4) were adopted as evaluation indexes to optimize the irrigationdrainage scheme. As was calculated by the PP model, the maximum index value of the projection was 0.6163 , and the best projection direction was $a_{(j)} *=0.5725,0.1808$, $0.5710,0.3009,0.0034,0.4722$. Projection value from I1D1 to control was ordered to be $z_{(i)} *=1.3606,1.5737$, $1.6724,1.4254,1.3655,1.3606,1.0929,0.9214,1.3605$, 0.0350 . A higher projection value indicated a better comprehensive effect for the treatment. I3D1 therefore was the optimal irrigation-drainage treatment due to its highest projection value of 1.6724 .

Table 5. The main quality indexes with different irrigation-drainage scheme used for calculating the comprehensive quality index of tomato

\begin{tabular}{|c|c|c|c|c|c|c|}
\hline Treatment & $\begin{array}{l}\text { Density } \\
\mathrm{g} \mathrm{cm}^{-3}\end{array}$ & $\begin{array}{c}\text { Volume } \\
\mathrm{cm}^{-3}\end{array}$ & $\begin{array}{c}\text { Soluble solid } \\
\%\end{array}$ & 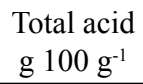 & $\begin{array}{l}\text { Vitamin C } \\
\text { mg } 100 \mathrm{~g}^{-1}\end{array}$ & Sugar:acid ratio \\
\hline I1D1 & $0.932 \mathrm{a}$ & $123.3 \mathrm{bc}$ & $6.6 \mathrm{a}$ & $0.58 \mathrm{~cd}$ & $13.1 \mathrm{ab}$ & $8.9 \mathrm{abc}$ \\
\hline I2D1 & $0.929 \mathrm{a}$ & $129.7 \mathrm{~b}$ & $5.6 \mathrm{~cd}$ & $0.61 \mathrm{bc}$ & $11.3 \mathrm{c}$ & $8.5 \mathrm{bc}$ \\
\hline I3D1 & $0.923 \mathrm{a}$ & $142.9 \mathrm{a}$ & $6.4 \mathrm{ab}$ & $0.63 \mathrm{abc}$ & $13.4 \mathrm{ab}$ & $9.3 \mathrm{ab}$ \\
\hline I1D2 & $0.932 \mathrm{a}$ & $122.4 \mathrm{bc}$ & $6.6 \mathrm{a}$ & $0.64 \mathrm{abc}$ & $13.6 \mathrm{ab}$ & $9.5 \mathrm{ab}$ \\
\hline $\mathrm{I} 2 \mathrm{D} 2$ & $0.925 \mathrm{a}$ & $125.8 \mathrm{bc}$ & $6.2 \mathrm{abc}$ & $0.59 \mathrm{c}$ & $12.5 \mathrm{bc}$ & $9.2 \mathrm{ab}$ \\
\hline $\mathrm{I} 3 \mathrm{D} 2$ & $0.922 \mathrm{a}$ & $133.4 \mathrm{ab}$ & $5.7 \mathrm{bcd}$ & $0.50 \mathrm{~d}$ & $11.1 \mathrm{c}$ & $8.0 \mathrm{c}$ \\
\hline I1D3 & $0.933 \mathrm{a}$ & $121.2 \mathrm{bc}$ & $6.4 \mathrm{ab}$ & $0.71 \mathrm{a}$ & $14.3 \mathrm{a}$ & $9.8 \mathrm{a}$ \\
\hline I2D3 & $0.932 \mathrm{a}$ & $125.6 \mathrm{bc}$ & $5.3 \mathrm{~d}$ & $0.64 \mathrm{abc}$ & $13.2 \mathrm{ab}$ & $9.6 \mathrm{ab}$ \\
\hline I3D3 & $0.926 \mathrm{a}$ & $128.2 \mathrm{bc}$ & $5.1 \mathrm{~d}$ & $0.60 \mathrm{c}$ & $12.6 \mathrm{abc}$ & $7.8 \mathrm{c}$ \\
\hline $\mathrm{CK}$ & $0.936 \mathrm{a}$ & $114.6 \mathrm{c}$ & $6.8 \mathrm{a}$ & $0.70 \mathrm{ab}$ & $14.1 \mathrm{ab}$ & $10.0 \mathrm{a}$ \\
\hline
\end{tabular}

Table 6. Electrical conductivity (EC)-decreasing rate, comprehensive nutrient index (CNI) and comprehensive quality index (CQI)

\begin{tabular}{ccccccccccc}
\hline Index & I1D1 & I2D1 & I3D1 & I1D2 & I2D2 & I3D2 & I1D3 & I2D3 & I3D3 & Control \\
\hline EC-decreasing rate \% & 45.50 & 50.77 & 51.29 & 39.72 & 42.42 & 42.67 & 24.55 & 38.95 & 45.37 & 10.93 \\
CNI & 1.09 & 2.27 & 2.50 & 1.64 & 1.57 & 3.29 & 1.00 & 1.76 & 2.16 & 1.40 \\
CQI & 2.19 & 1.58 & 2.28 & 2.85 & 2.17 & 1.35 & 2.71 & 1.95 & 1.00 & 3.13 \\
\hline
\end{tabular}

Notes. CNI represents the soil comprehensive nutrient index calculated by principal component analysis (PCA) according to the content of soil available N, P and K in plough layer. Similarly, CQI represents the tomato comprehensive quality index calculated according to the content of fruit volume, density, soluble solids, total acid, vitamin $\mathrm{C}$ and sugar:acid ratio.

\section{Discussion}

In our study, the treatments achieved an EC decrease rate of $24.6-51.3 \%$. The experiment using drip irrigation which was conducted in salt-affected soils in west side of the San Joaquin Valley of California also obtained similar results in controlling soil salinity (Hanson, May, 2004). However, the EC decrease rate could only reflect the variation tendency of soil salt, but could not represent the real removing rate of the salt, because the EC was dynamically changed (Zhang,
Chang, 2012). After surface drainage, EC in SOM with most treatments was decreased, possibly not only due to the fact that the drainage waters brought away the soil soluble salts through runoffs, but also due to the fact that the waters leached the salt into deeper soil layer (Bao et al., 2013). Besides, EC was related closely to the soil evaporation. Higher soil evaporation would lead to higher soil resalinization (Zhao et al., 2013). The soil EC in SOM under some of the treatments increased after drainage probably because the resalination was more significant than desalination (Chang et al., 2013). 
Higher irrigation quota was easier to cause the loss of soil nutrients. An appropriate irrigation quota was conductive to the mineralization of fertilizer elements (Fließbach et al., 2007). In this study, the mulched drip irrigation and surface drainage had only small effects on the soil available nutrient content as measured at the end of the experiment, but an obvious increase of NUE was detected under higher irrigation quota, perhaps because the increased available $\mathrm{N}$ caused by the irrigations had been absorbed by the tomato plants, consequently the soil available $\mathrm{N}$ content was maintained in a stable status.

An increase rate of $14.4-31.3 \%$ in marketable yield of tomato was obtained by the treatments when compared to control. Higher yield was in correspondence with higher irrigation quota, this result agreed with the findings of Zhai et al. (2015). The yield-increase effects by drip irrigation were also reported in Ayars's and coauthors (1999) study. Similar study by Biswas et al. (2015) observed a yield-increase rate of $25-27 \%$ under mulched drip irrigation when compared to the control. Meanwhile, the WUE of tomato was increased by $0.3-24.2 \%$. Values of WUE were negatively correlated to the irrigation quota, which confirmed the study by Zhang et al. (2011). Otherwise, ditch depth was found to have slight effects on WUE, this was probably due to the fact that different ditch depth resulted in different profile distributions of soil moisture. Besides, the negative relationship between irrigation quota and overall tomato quality in our study agreed with the results by many early studies (Liu et al., 2011; Patanè et al., 2011).

Various indexes should be taken into consideration when optimizing the irrigation and drainage scheme. The optimization process needed the multi-index evaluation model due to the specifics of high-dimensional data. To avoid the uneven distribution of index weight caused by the various subitems in one index, the subitems should be pretreated in order to summarize them into one comprehensive index (Hou, 2013). Early study by Yan (2014) used the PCA to pretreat the various subitems of flue-cured tobacco quality to evaluate the overall tobacco quality, and then used the entropy weight coefficient evaluation model to optimize water-nitrogen coupling scheme. Similarly, the PCA and PP models were adopted in our study, which were expected to provide useful information for further studies. Besides the conventional indexes of salt-decreasing rate and crop yield, our study increased other evaluation indexes including WUE, NUE, soil nutrient and crop quality, and established a more detailed evaluation index system. In our study, the optimal value of the six evaluation indexes could not be simultaneously obtained by one treatment, especially the quality and yield. Higher irrigation quota produced more marketable yield of tomato but also lowered the overall tomato quality. Therefore, it was vital to find the compromises between different evaluation indexes especially between tomato quality and yield. As was calculated by PP model, I3D1 was evaluated to be the optimal irrigation-drainage scheme. I3D1 obtained the highest saltdecreasing rate, suboptimal NUE and marketable yield, satisfactory soil nutrient, while the overall tomato quality and WUE were not significantly lowered.

\section{Conclusions}

1. Higher irrigation quota increased tomato marketable yield and nitrogen use efficiency (NUE), whereas decreased the water use efficiency (WUE) of tomato. The depth of drain ditch had some effects on the value of electrical conductivity (EC) in the sampling locations outside the mulch (SOM) and the WUE, but had no significant effects on other indicators such as NUE and tomato marketable yield.

2. I3D1 $\left(300 \mathrm{~m}^{3} \mathrm{hm}^{-2}\right.$ of irrigation quota combined with $10 \mathrm{~cm}$ of ditch depth) was the treatment with optimal comprehensive benefits due to the highest projection value of 1.6724 according to the calculated results by the projection pursuit (PP) model.

Received 16122015

Accepted 17032016

\section{References}

Ayars J. E., Phene C. J., Hutmacher R. B., Davis K. R., Schoneman R.A., Vail S. S., Mead R. M. 1999. Subsurface drip irrigation of row crops: a review of 15 years of research at the Water Management Research Laboratory. Agricultural Water Management. 42: 1-27

http://dx.doi.org/10.1016/S0378-3774(99)00025-6

Bao T. F., Huang, W. B., Chen X. D., Xu M., Hou M. M. 2013. The effect of subsurface drainage system on soil condition and tomato quality. Journal of Food, Agriculture and Environment, 11: 331-335

Biswas S. K., Akanda A. R., Rahman M. S., Hossain M. A. 2015. Effect of drip irrigation and mulching on yield, water-use efficiency and economics of tomato. Plant, Soil and Enironment. 61: 97-102 http://dx.doi.org/10.17221/804/2014-PSE

Chang T. T., Shao X. H., Zhang J., Mao J. G., Wei Y. G., Yin C., Wang W. N. 2013. Effects of bio-organic fertilizer application combined with subsurface drainage in secondary salinized greenhouse soil. Journal of Food Agriculture and Environment, 11: 457-460

Chen J. L., Kang S. Z., Du T. S., Qiu R. J., Guo P., Chen R. Q. 2013. Quantitative response of greenhouse tomato yield and quality to water deficit at different growth stages. Agricultural Water Management. 129: 152-162 http://dx.doi.org/10.1016/j.agwat.2013.07.011

Croux C., Filzmoser P., Oliveira M. R. 2007. Algorithms for Projection-pursuit robust principal component analysis. Chemometrics and Intelligent Laboratory Systems, 87: 218-225 http://dx.doi.org/10.1016/j.chemolab.2007.01.004

Fließbach A., Oberholzer H., Gunst L., Mäder P. 2007. Soil organic matter and biological soil quality indicators after 21 years of organic and conventional farming. Agriculture, Ecosystems and Environment, 118: 273-284 http://dx.doi.org/10.1016/j.agee.2006.05.022

Hanson B., May D. 2004. Effect of subsurface drip irrigation on processing tomato yield, water table depth, soil salinity, and profitability, Agricultural Water Management, 68: 1-17 http://dx.doi.org/10.1016/j.agwat.2004.03.003

Hou M. M. 2013. Entropy weight coefficient evaluation of comprehensive index for flue-cured tobacco and its response to different water-nitrogen treatments. Research on Crops, 14: 1232-1237

Hou M. M., Shao X. H., Chen L. H. 2012. Study on fertilizer $\mathrm{N}$ leaching, accumulation, and balance in tobacco fields with N-15 tracing technique. Journal of Food, Agriculture and Environment, 10: 1284-1289

Liu K., Zhang T. Q., Tan C. S., Astatkie T., 2011. Responses of fruit yield and quality of processing tomato to dripirrigation and fertilizers phosphorus and potassium. Agronomy Journal, 103: 1339-1345 http://dx.doi.org/10.2134/agronj2011.0111

Ma L. 2009. Optimal selection of water-saving irrigation project scheme based on Projection pursuit model. Water Saving Irrigation, 10: 28-34

Mahajan G., Singh K. G. 2006. Response of greenhouse tomato to irrigation and fertigation. Agricultural Water Management, 84: 202-206 http://dx.doi.org/10.1016/j.agwat.2006.03.003 
Parris K. 2011. Impact of agriculture on water pollution in OECD countries: recent trends and future prospects. International Journal of Water Resources Develonment. 27: 33-52 http://dx.doi.org/10.1080/07900627.2010.531898

Patanè C., Tringali S., Sortino O. 2011. Effects of deficit irrigation on biomass, yield, water productivity and fruit quality of processing tomato under semi-arid Mediterranean climate conditions. Scientia Horticulturae. 129: 590-596 http://dx.doi.org/10.1016/j.scienta.2011.04.030

Raina J. N., Thakur B. C., Verma M. L. 2013. Effect of drip irrigation and polyethylene mulch on yield, quality and water-use efficiency of tomato (Lycopersicon esculentum) The Indian Journal of Agricultural Sciences, 69: 114-121

Shao G. C., Zhang Z. Y. 2007. Application of projection pursuit model to evaluate under mulch drip irrigation scheme. Journal of Hydraulic Engineering, 38: 944-952

Shao G. C., Wang M. H., Liu N., Yuan M., Kumar P., She D. L. 2014. Growth and comprehensive quality index of tomato under rain shelters in response to different irrigation and drainage treatments. The Scientific World Journal, 2014: 12 http://dx.doi.org/10.1155/2014/457937

Shao X. H., Hou M. M., Chen L. H., Chang T. T., Wang W. N. 2012. Evaluation of subsurface drainage design based on projection pursuit. Energy Procedia, 16: 747-752 http://dx.doi.org/10.1016/j.egypro.2012.01.120

Vázquez N., Pardo A., Suso M. L., Quemada M. 2006. Drainage and nitrate leaching under processing tomato growth with drip irrigation and plastic mulching. Agriculture, Ecosystems and Environment, 112: 313-323 http://dx.doi.org/10.1016/j.agee.2005.07.009

Wan S. Q., Kang Y. H., Wang D., Liu S. P., Feng L. P. 2007. Effect of drip irrigation with saline water on tomato (Lycopersicon esculentum Mill) yield and water use in semi-humid area. Agricultural Water Management. 90: 63-74 http://dx.doi.org/10.1016/j.agwat.2007.02.011

Xing Y. Y., Zhang F. C. 2015. Effect of irrigation and fertilizer coupling on greenhouse tomato yield, quality, water and nitrogen utilization under fertigation. Scientia Acricultura Sinica, 48: 713-726

Yan J. W. 2014. 15N tracing technique based evaluation of entropy weight coefficients of water and nitrogen coupling schemes for flue-cured tobacco. Journal of Northwest A and F University, 42: 1-6

Zhai Y. M., Yang Q., Hou M. M. 2015. The effects of saline water drip irrigation on tomato yield, quality, and blossom-end rot incidence - a 3a case study in the South of China. Plos ONE. 10 ID0142204.

http://dx.doi.org/10.1371/journal.pone.0142204

Zhang H. X., Chi D. C., Wang Q., Fang J., Fang X. 2011. Yield and quality response of cucumber to irrigation and nitrogen fertilization under subsurface drip irrigation in solar greenhouse. Agricultural Sciences in China. 10: 921-930 http://dx.doi.org/10.1016/S1671-2927(11)60077-1

Zhang J., Chang T. T. 2012. Improvement effect of subsurface drainage on secondary salinizaition of greenhouse soils and tomato yield. Transactions of the Chinese Society of Agricultural Engineering, 28: 81-86

Zhao Y. G.., Wang J., Li Y. Y., Pang H. C. 2013. Reducing evaporation from phreatic water and soil resalinization by using straw interlayer and plastic mulch. Transactions of the Chinese Society of Agricultural Engineering, 29: 109-117

Zotarelli L., Dukes M. D., Scholberg J., Munoz-Carpena R., Icerman J. 2009. Tomato nitrogen accumulation and fertilizer use efficiency on a sand y soil, as affected by nitrogen rate and irrigation scheduling. Agricultural Water Management. 96: 1247-1258 http://dx.doi.org/10.1016/j.agwat.2009.03.019

ISSN 1392-3196 / e-ISSN 2335-8947

Zemdirbyste-Agriculture, vol. 103, No. 2 (2016), p. 221-228

DOI $10.13080 /$ z-a.2016.103.029

\title{
Drèkinimo ir drenažo schemos pomidorams optimizavimas taikant daugiarodiklę analizę bei projekcijos modelį
}

\author{
M. Hou ${ }^{1}$ X. Shao ${ }^{2,3}$ \\ ${ }^{1}$ Fujian žemès ūkio ir miškininkystès universiteto Sodininkystės kolegija, Kinija \\ ${ }^{2}$ Pietų Kinijos efektyvaus drèkinimo bei drenažo ir žemès ūkio dirvožemio bei vandens aplinkos tyrimų \\ laboratorija \\ ${ }^{3}$ Hohai universiteto Vandens apsaugos ir hidroenergijos inžinerijos kolegija, Kinija
}

\section{Santrauka}

Žemès ūkio augalams kuriant tinkamą drèkinimo ir drenažo sistemą, reikia atsižvelgti ị įvairius rodiklius. Tyrimui pasirinkti pomidorai kaip augalinė medžiaga ir atlikti lauko eksperimentai druskingose dirvožemiuose. Devyni tyrimo variantai, besiskiriantys drékinamojo vandens kiekiu ir drenažo grioviu gyliu, naudoti optimizuojant drèkinimo ir drenažo sistemą. Kontrolinis variantas buvo drèkinimas potvynio vandeniu be paviršinio drenažo. Vertinimo rodiklių sistemą sudare šeši rodikliai: dirvožemio elektrinis laidumas, maisto medžiagų kiekis jame, vandens ir azoto panaudojimo efektyvumas, pomidoru kokybè ir prekinis derlius. Be to, daugelio rodikliu analizè ir projekcijos modelis naudoti siekiant drékinimo ir drenažo schemas ịvertinti pagal šių rodiklių vertes. Tyrimo rezultatai parodè, kad skirtingi drèkinimo ir drenažo variantai dirvožemio ariamajame sluoksnyje $24,6-51,3 \%$ sumažino elektrinį laidumą ir $0,3-24,2$ bei $20,3-96,0 \%$ padidino pomidoru vandens panaudojimo efektyvumą. Palyginus su kontroliniu variantu, drẻkinimo ir drenažo variantuose pomidorų prekinis derlius padidejo 14,4$31,3 \%$. taikant projekcijos modeli nustatyta, kad dèl didžiausios projekcijos vertès $(1,6724)$ naudingiausias buvo I3D1 $\left(300 \mathrm{~m}^{3} \mathrm{hm}^{-2}\right.$ drèkinimui skirto vandens kiekis kartu su $10 \mathrm{~cm}$ drenažo gyliu) variantas, todèl jis yra rekomenduotinas kaip optimali drëkinimo ir drenažo schema.

Reikšminiai žodžiai: drèkinamojo vandens kiekis, lašelinis drèkinimas, paviršinis drenažas, pagrindinių komponenčių analizè, projekcijos vykdymas.

Please use the following format when citing the article:

M. Hou, X. Shao. 2016. Optimization of irrigation-drainage scheme for tomato crop based on multi-index analysis and projection pursuit model. Zemdirbyste-Agriculture, 103 (2): 221-228 DOI 10.13080/z-a.2016.103.029 